\title{
APEX2 wt Allele
}

National Cancer Institute

\section{Source}

National Cancer Institute. APEX2 wt Allele. NCI Thesaurus. Code C50978.

Human APEX2 wild-type allele is located in the vicinity of Xp11.21 and is approximately 7 $\mathrm{kb}$ in length. This allele, which encodes DNA-(apurinic or apyrimidinic site) lyase 2 protein, is involved in base excision repair. 